\title{
Mir-30b-3p affects the migration and invasion function of ovarian cancer cells by targeting the CTHRC1 gene
}

Yan $\mathrm{Li}^{1,2+}$, Jinhua Zhou ${ }^{1+}$, Juan Wang ${ }^{1 \dagger}$, Xiaoping Chen ${ }^{2}$, Yan Zhu ${ }^{2}$ and Youguo Chen ${ }^{1 *}$

\begin{abstract}
Background: The aim of this study was to investigate the effect role and mechanism of miR-30b-3p on ovarian cancer cells biological function.

Methods: The expression of miR-30b-3p was detected in ovarian cancer cell lines and normal ovarian epithelial cell line by qRT-PCR. Mir-30b-3p mimic was transfected into OVCAR3 cells. Cell-counting kit-8 (CCK-8) assay was conducted to explore the effect of mir-30b-3p on the OVCAR3 cells' proliferation. Cell cycle and apoptosis were detected by Flow cytometry. Cell invasion ability was detected by Transwell test. The regulation of putative target of miR$30 \mathrm{~b}-3 \mathrm{p}$ was verified by double luciferase reporter assays and Western blot.

Result: We found that miR-30b-3p was downregulated in OVCAR3 cells. Overexpression of miR-30b-3p suppressed proliferation, promoted apoptosis, slowed cell cycle and inhibited migration and invasion of OVCAR3 cells. Bioinformatics analysis identified $3^{\prime}$-untranslated region (3'UTR) of Collagen triple helix repeat-containing 1 (CTHRC1) as the presumed binding site for miR-30b-3p. Detection of double luciferase reporter and Western-Blot result confirmed that CTHRC1 was the target gene of miR-30b-3p. Furthermore, E-cadherin, $\beta$-cadherin and Vimentin protein expression level were changed after transfection of miR-30b-3p.
\end{abstract}

Conclusion: miR-30b-3p function as an anti-cancer gene. Overexpression of miR-30b-3p can inhibit the biological function of ovarian cancer cells. MiR-30b-3p targets CTHRC1 gene plays an important role in epithelial-mesenchymal transformation (EMT), and supports miR-30b-3p as a potential biological indicator for ovarian cancer in the future.

Keywords: miR-30b-3p, Ovarian cancer, OVCAR3, CTHRC1, EMT

\section{Background}

Ovarian cancer is one of the three major gynecological malignancies, with about 240,000 new cases and 150,000 deaths worldwide every year [1]. It is the most common cause of gynecological malignancy death. The tragic outcomes of ovarian cancer are mainly late diagnosis as it is

\footnotetext{
*Correspondence: zongfang5581847147@163.com; youguo_chen@163.com

'Yan Li, Jinhua Zhou and Juan Wang contributed equally to the article, shall be regarded as co-first authors

${ }^{1}$ Department of Obstetrics and Gynecology, The First Affiliated Hospital of Soochow University, 188 Shizi Road, Suzhou 215006, Jiangsu, People's Republic of China

Full list of author information is available at the end of the article
}

generally lack of obvious symptoms [2]. The 5-year survival rate for FIGO stage I patients with ovarian cancer is as high as $90 \%$, while the 5 -year survival rate for stage III or IV patients remains at less than $30 \%$ [3]. Hence, it is urgent to provide more reliable prognosis biomarker to effectively diagnose early and evaluate the prognosis of ovarian cancer. Currently, common clinical markers of ovarian cancer include CA125, CA153 and CEA, but the specificity and sensitivity of these markers are low.

It is the basis of diagnosis and treatment of ovarian cancer to find out the pathogenesis of ovarian cancer from the genetic approach. MicroRNA (miRNA) is endogenous small non-coding RNA with a length of 19 to

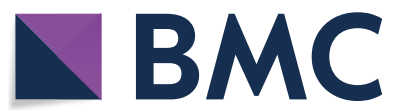

(c) The Author(s) 2020. This article is licensed under a Creative Commons Attribution 4.0 International License, which permits use, sharing, adaptation, distribution and reproduction in any medium or format, as long as you give appropriate credit to the original author(s) and the source, provide a link to the Creative Commons licence, and indicate if changes were made. The images or other third party material in this article are included in the article's Creative Commons licence, unless indicated otherwise in a credit line to the material. If material is not included in the article's Creative Commons licence and your intended use is not permitted by statutory regulation or exceeds the permitted use, you will need to obtain permission directly from the copyright holder. To view a copy of this licence, visit http://creativeco mmons.org/licenses/by/4.0/. The Creative Commons Public Domain Dedication waiver (http://creativecommons.org/publicdomain/ zero/1.0/) applies to the data made available in this article, unless otherwise stated in a credit line to the data. 
25 nucleotides, which can regulate target gene expression by binding to $3^{\prime}$ UTR [4]. MiRNAs are involved in many cancer-related biological processes, including tumor genesis, cell proliferation, differentiation and apoptosis, angiogenesis, invasion and metastasis, tumor resistance, and prognosis [5]. Moreover, emerging evidence suggests that miRNAs are present not only in cell but also in circulating blood, reflecting the conditions of tissue or organ [6, 7]. It has become increasingly important to study the mechanism of miRNA's influence on tumorigenesis.

The miRNA-30 family includes miR-30a, miR-30b, miR30c-1, miR-30c-2, miR-30d, miR-30e, encoded by six genes located on human chromatids 1,6 , and 8 [8]. It has been reported that miR-30 family express disorders in lung cancer, breast cancer, multiple myeloma, colorectal cancer, liver cancer, bladder cancer, endometrial cancer and other cancers $[8,9]$. Furthermore, recent evidence has demonstrated that miR-30 families can act on the cell signaling pathway of corresponding target genes and affect the development, metastasis, apoptosis and drug resistance of ovarian cancer cells, which is expected to be a potential biomarker and therapeutic target of ovarian cancer. However, the regulatory mechanism of miR-30b-3p in response to ovarian cancer remain unclear. The current study was performed with the aim of investigating the effect and mechanism of miR30b-3p on the biological function of ovarian cancer cells. To evaluate the potential of miR-30b-3p as a biomarker of ovarian cancer, the expression level of miR-30b-3p in ovarian cancer cell were analyzed and compared with those of normal ovarian epithelial cells. We analyzed the effect of mir-30b-3p on the proliferation, cell cycle, migration and invasion of ovarian cancer cells, and investigated whether this effect was related to the CTHRC1.

\section{Methods}

\section{Materials}

Human ovarian cancer epithelial cell line OVCAR3 and human normal ovarian epithelial cell line IOSE80 were purchased from ATCC cell bank in the United States. Cell culture reagents (DEME medium, fetal bovine serum, streptomycin penicillin, trypsin) were purchased from Gibco, USA. Cell proliferation activity assay Kit CCK-8 was purchased from Tongren Institute of Chemistry, Japan. miRNA extraction kit, miRNA reverse transcription and fluorescence quantitative kit, and Lipofectamine TM 2000 transfection kit were all purchased from Invitrogen, USA. Mir-30b-3p, mimics and mimic control miRNAs were synthesized by Shanghai Gemar Pharmaceutical Technology Co., LTD., China. Mir-30b-3p and U6 primers were designed and synthesized by bioengineering (Shanghai) Co., LTD., China. ECL chemiluminescence reagent and $\mathrm{BCA}$ protein concentration detection kit were purchased from Shanghai Biyuntian
Biotechnology Co., LTD., China. The dual luciferase report detection system is the product of Promega, USA.

\section{Cell culture}

After resuscitation of human ovarian cancer epithelial cell line OVCAR3 and human normal ovarian epithelial cell line IOSE80, DEMN medium containing 10\% fetal bovine serum and $1 \%$ dual antibody was used for culture, and incubated at $5 \% \mathrm{CO}_{2}$ and $37^{\circ} \mathrm{C}$. The medium was changed once a day. Digestion, passage and inoculation were carried out after the degree of cell fusion $>80 \%$ for follow-up research.

\section{Quantitative reverse transcription polymerase chain reaction (qRT-PCR) of miR-30b-3p}

OVCAR3 cells and IOSE80 cells were collected at logarithmic growth stage. Total RNA was extracted and transcribed back into cDNA. mir-30b-3p expression was detected using $\mathrm{U} 6$ as the internal reference The forward and reverse primers for miR-30b-3p were $5^{\prime}$-GCTGCGGTGTAGACA TCTAATAC- $3^{\prime}$ and $5^{\prime}$-ATCCAGTGCAGGGTCCGA CC-3', and for U6 were $5^{\prime}$-CTCGCTTCGGCAGCACA$3^{\prime}$ and $5^{\prime}$-AACGCTTCACGAATTTGCGT-3'. The relative expression of mir-30b-3p was calculated according to $2^{-\Delta \Delta \mathrm{Ct}}$, and expression was shown relative to U6.

\section{Cell transfection}

OVCAR3 cells at logarithmic growth stage were digested and collected. Inoculate in six-well plates at a density of $10^{6} /$ well. After $24 \mathrm{~h}$ culture, mir-30b-3p mimic and mimic control were transfected into OVCAR3 cells using Lipofectamine $^{\mathrm{TM}} 2000$ transfection reagent according to the kit operation protocol.

\section{Cell proliferation was detected using the CCK-8 assay}

Human ovarian cancer OVCAR3 cells were further cultured after transfection with mir-30b-3p mimic and noload plasmid, and the proliferation and activation capacity of the cells were measured after $48 \mathrm{~h}$, respectively. Cell were harvested and seeded into 96-well plates at a density of $10^{4}$ cells/well. Each group of cells was set up with 3 repeating holes. Following incubation of cell for 0, 24, 48 , and $72 \mathrm{~h}$, the CCK- 8 reagent of $20 \mu \mathrm{L}$ was add to each well. The OD490 values was detected by an automatic enzyme marker, which was assessed the number of viable cell.

Flow cytometry was used to detect cell cycle and apoptosis Cells were stained with propidium iodide (PI) and the cell cycle distribution and apoptosis rate were detected by flow cytometry. Firstly, the dye PI [containing $50 \mathrm{mg} / \mathrm{L}$, $20 \mathrm{mg} / \mathrm{L}$ ribonuclease (RNase) A, $1 \mathrm{~g} / \mathrm{L}$ sodium citrate, $\mathrm{pH}$ 7.4] was prepared, and stored at $4{ }^{\circ} \mathrm{C}$ away from light. Two groups of cells were cultured for $48 \mathrm{~h}$ after 
transfection, the cells were washed with phosphate buffer solution (PBS) and fixed with $75 \%$ ethanol, discarded supernatant after centrifugal. Precooled PBS was added, and the supernatant was discarded after centrifuged again, and then collected the cells. RNase A reagent was added to digest the cells for $30 \mathrm{~min}$, and then PI solution was added for staining for $30 \mathrm{~min}$ under $4{ }^{\circ} \mathrm{C}$. Samples were transferred to the detection tube of flow cytometer for detection. Cell cycle distribution and apoptosis rate were measured according to the changes of DNA content at various stages of cell mitosis.

\section{Cell migration and invasion was detected by Transwell assay}

The upper chamber of the Transwell plate was coated with Matrigel of $1 \mathrm{mg} / \mathrm{mL}$, and DMEM medium was added to the lower chamber. $2 \times 10^{5}$ OVCAR3 cells were seeded in an upper chamber and cultured at indoor temperature. Cells migrated or infiltrated into the lower chamber were fixed and stained with crystal violet. Randomly selected fields were placed under the microscope for counting.

\section{The target gene of mir-30b-3p was verified by double luciferase activity assay}

Wild-type and mutant CTHRC1 double luciferase reporter plasmids were constructed and named CTHRC1-wt3'-UTR and CTHRC1-mut3'-UTR, respectively. $1 \times$ Passive Lysis Buffer $300 \mu \mathrm{L}$ was used to lyse the cells. $40 \mu \mathrm{L}$ cell lysate was absorbed into the Lockwell maxisorp Assay plate, added $20 \mu \mathrm{L}$ luciferase Assay Reagent, and the fluorescence value of luciferase was measured by elisa immediately after shaking and mixing. After adding $20 \mu \mathrm{L}$ Stop \& Glo ${ }^{\circledR}$ Reagent for each well, use the enzyme marker to detect the fluorescence value of sea kidney luciferase.

\section{Detection of CTHRC1 protein expression in OVCAR3 cells}

The expression of CTHRC1 was detected by Western blot. The cells were lysed in RIPA buffer, and the concentrations of cell proteins were determined according to the BCA kit. Samples were denatured by boiling for $5 \mathrm{~min} .40 \mu \mathrm{g}$ total protein separated on $10 \%$ SDS-PAGE (70 V, $30 \mathrm{~min} ; 100 \mathrm{~V}, 90 \mathrm{~min}$ ) and transfer to PVDF membrane (200 mA, $3 \mathrm{~h})$. Membranes were then blocked in $5 \%$ non-fat milk and incubated with primary antibody (1:500) overnight at $4{ }^{\circ} \mathrm{C}$. The next day, the membrane was washed with TPBS and PBS and incubated with secondary antibodies. And then performed Western blot.

\section{Statistical analysis}

The potential target genes of miR-30b-3p were identified by an online tool of miRNA target prediction database (Trargetscan.org).

All experimental results were statistically analyzed by SPSS 18.0 or Graph prism software. Measurement data are expressed as mean \pm standard. $t$ test was used to compare the two groups and analysis of variance was used to compare the three groups. $\mathrm{P}<0.05$ was considered statistically significant.
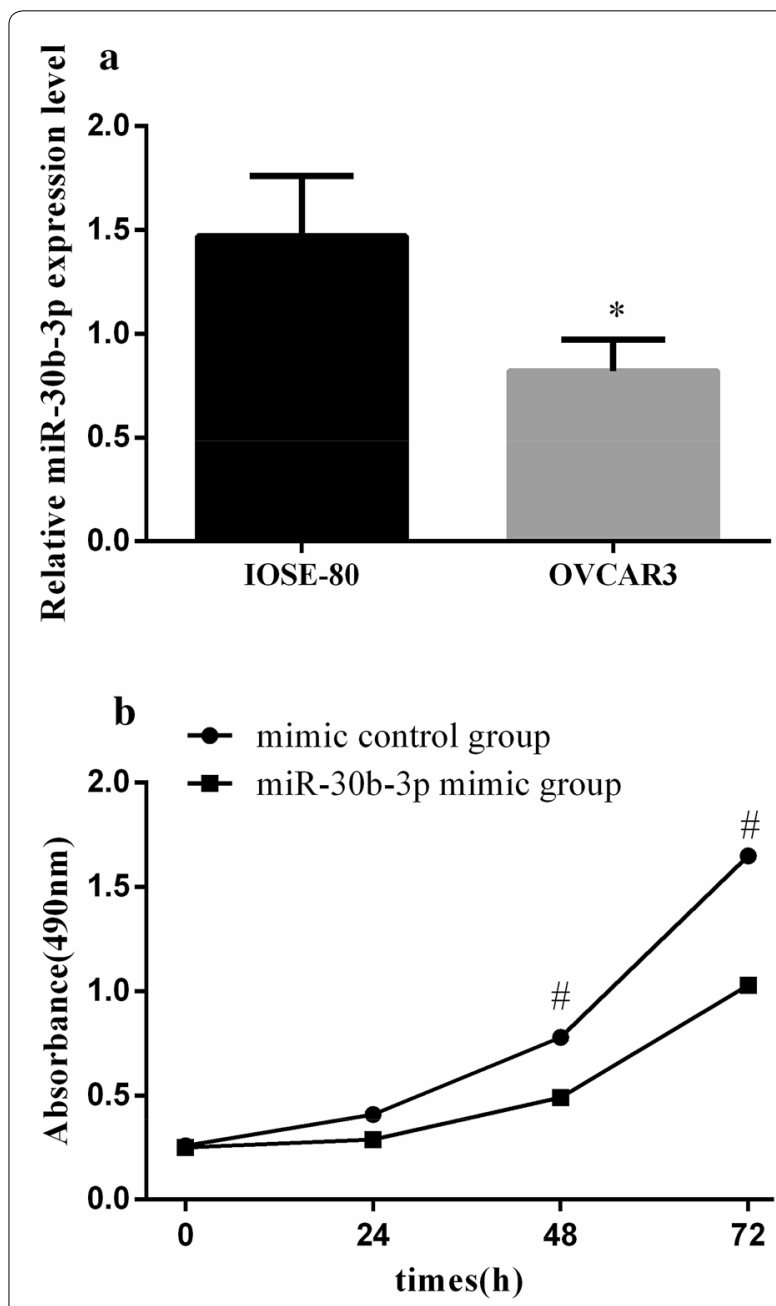

Fig. 1 The relative expression level of miR-30b-3p in different ovarian cells and the effect of overexpression miR-30b-3p on OVCAR3 cells. a The result of qRT-PCR shown that the expression in OVCAR3 cells were significantly lower than those in IOSE-80 cells. * Mean $\mathrm{P}<0.05$ vs IOSE-80 cells. b Cell proliferation was suppressed after transfection of mir-30b-3p. \#Mean $\mathrm{P}<0.05$ vs mir-30b-3p mimic group 


\section{Result}

The expression level of miR-30b-3p in ovarian cells

The expression of miR-30b-3p in human ovarian cancer epithelial cell line OVCAR3 cells was significantly lower than that in human normal ovarian epithelial cell line IOSE80 cells, and the difference was statistically significant $(\mathrm{P}<0.05)$ (Fig. 1a).

\section{High expression of miR-30b-3p suppresses OVCAR3 proliferation}

According to the cell transfection method, the cells were divided into mimic control group and mir-30b-3p mimic group. We investigated the effect of miR-30b-3p overexpression on cell proliferation by CCK- 8 assay (Fig. 1b). The cell proliferation ability of mir-30b-3p mimic group decreased after $48 \mathrm{~h}$, which was significantly lower than that of the mimic control group $(\mathrm{P}<0.05)$, indicating that the high expression of mir$30 \mathrm{~b}-3 \mathrm{p}$ could inhibit the proliferation of OVCAR3 cells.

\section{Transfection of miR-30b-3p can induced OVCAR3 cells} apoptosis and slowed the growth speed of OVCAR3 cells Flow cytometry was used to identify apoptosis and cell cycle in OVCAR3 cells (Fig. 2). The apoptosis rate of OVCAR3 cells transfected with miR-30b-3p were significantly higher than mimic control group cells $(\mathrm{P}<0.05)$. And the growth rate of mir-30b-3p mimic group was significantly slower than mimic control group $(\mathrm{P}<0.05)$. Cell cycle of OVCAR3 cells transfected with miR-30b-3p arrested in G0/G1 phase and $S$ phase cells number decreased (Table 1 ). The result suggested
Table 1 The division cycle of OVCAR3 cells ( $x \pm s, \%)$

\begin{tabular}{llll}
\hline Group & G0/G1 & G2/M & \multicolumn{1}{l}{ S } \\
\hline Mimic control group & $44.13 \pm 4.78^{\#}$ & $14.52 \pm 1.52$ & $37.87 \pm 3.42^{\#}$ \\
mir-30b-3p mimic group & $69.16 \pm 7.13$ & $9.66 \pm 1.45$ & $15.94 \pm 1.63$
\end{tabular}

\# Mean $\mathrm{P}<0.05$ vs mir-30b-3p mimic group

that $\mathrm{miR}-30 \mathrm{~b}-3 \mathrm{p}$ regulated the apoptosis and cell cycle of OVCAR3 cells.

\section{Transfection of miR-30b-3p suppressed OVCAR3 cell migration and invasion}

Transfection with miR-30b-3p significantly reduced the number of OVCAR3 cells passing through the polycarbonate membrane and inhibited the invasion ability of OVCAR3 cells, with statistically significant differences compared with the mimic control group $(\mathrm{P}<0.05)$ (Fig. 3).

\section{CTHRC1 is the target gene of miR-30b-3p}

Bioinformatics analysis was performed using online tool TargetScan to identify potential targets of miR-30b-3p. The result shown that CTHRC1 mRNA contained a $3^{\prime}$-UTR element that was complementary to miR-30b (Fig. 4a). Hence, we cloned the CTHRC1 3'-UTR region containing this complementary site into the luciferase reporter vector. Compared with the mimic control group, the luciferase activity of OVCAR3 cells transfected with this structure and miR-30b-3p was significantly
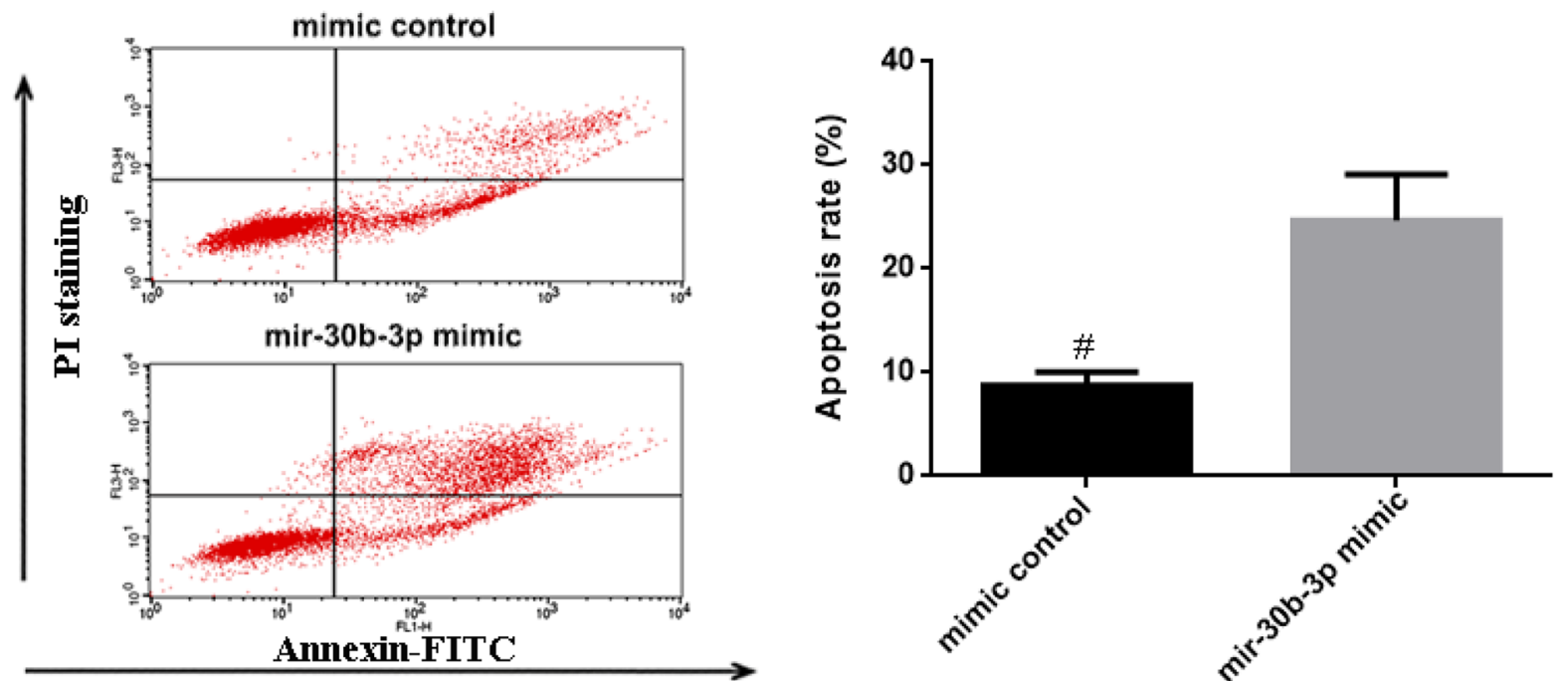

Fig. 2 The effect of miR-30b-3p on OVCAR3 cells' apoptosis. The apoptosis rate of mimic control group was $9.8 \%$; the apoptosis rate of mir-30b-3p mimic group was $26.90 \%$. "Mean $\mathrm{P}<0.05$ vs mir-30b-3p mimic group 


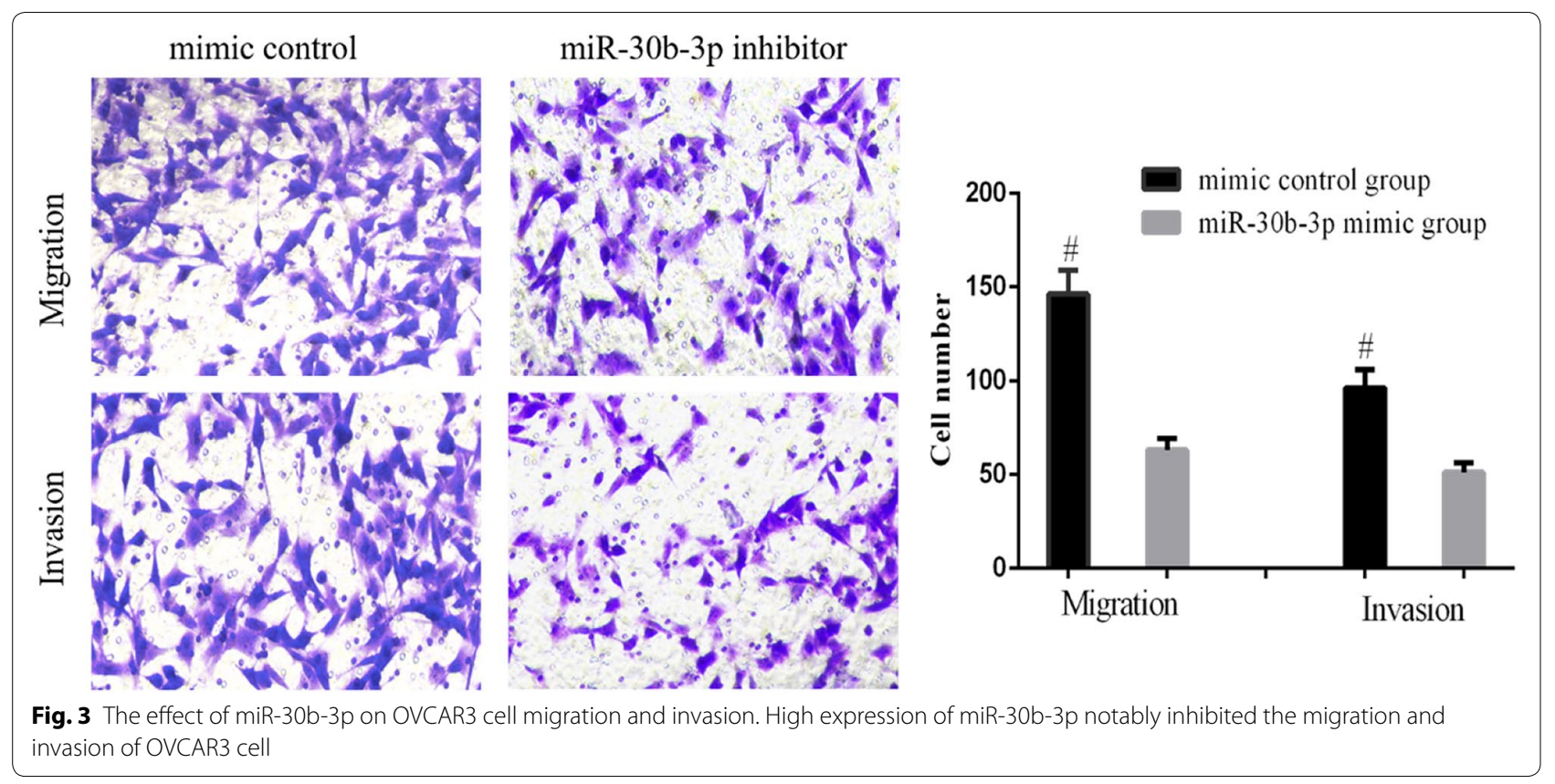

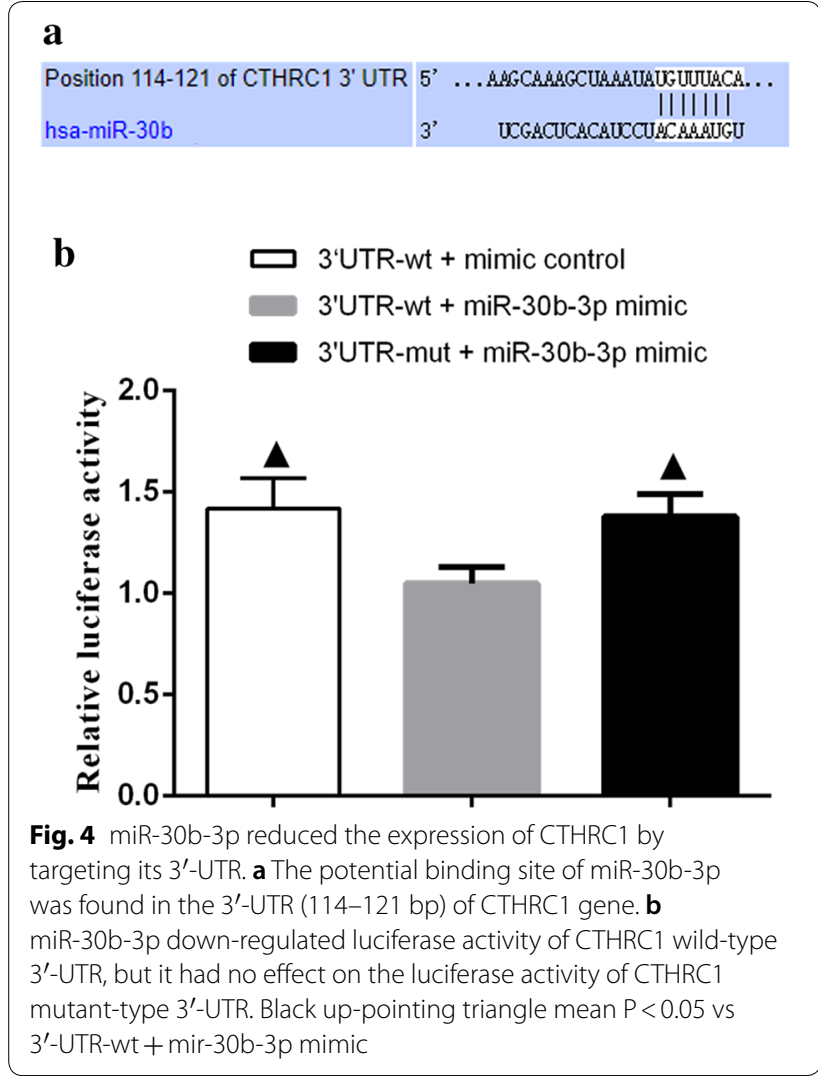

reduced. However, luciferase activity in cells transfected with reporter constructs containing suspected mir30b-3p target mutations was not affected by mir-30b-3p

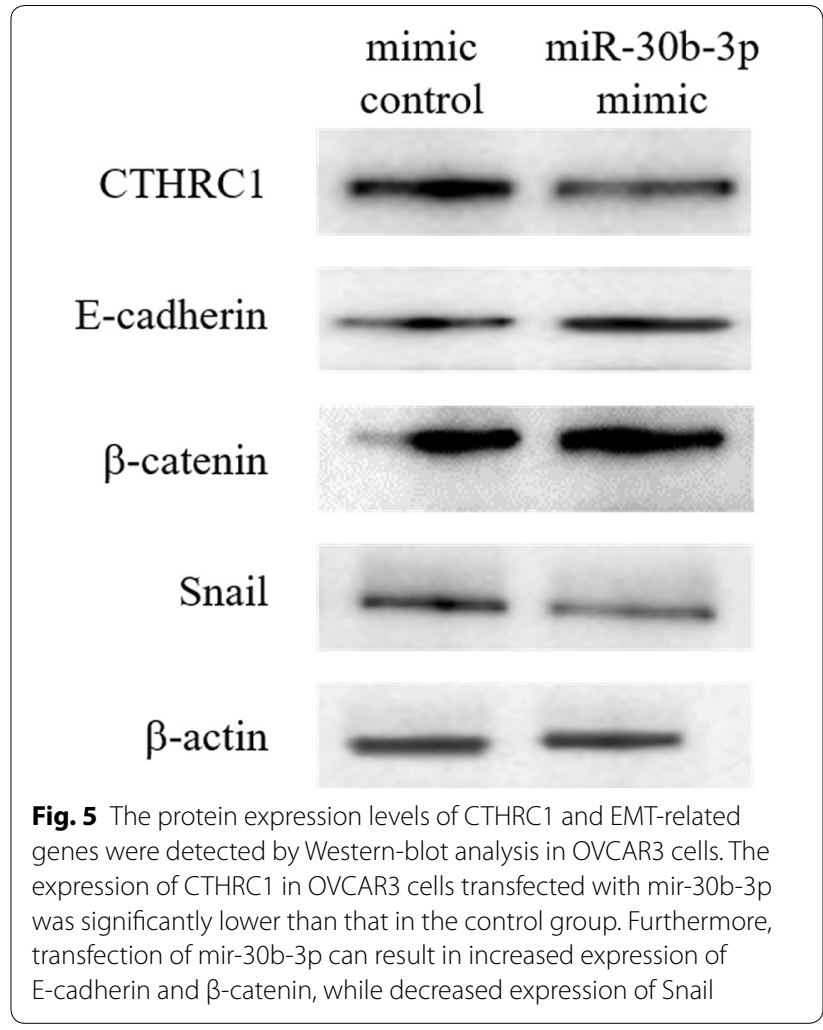

co-transfection (Fig. 4b), indicating that miR-30b-3p targeted on the $3^{\prime}$-UTR of CTHRC1. 


\section{MiR-30b-3p inhibits the expression of CTHRC1 protein}

The protein expression of CTHRC1 in cell transfected with miR-30b-3p was significantly lower than mimic control group. Furthermore, transfection with miR-30b-3p resulted in upregulated expression of E-cadherin and $\beta$-catenin, and downregulated expression of Snail. The results indicated that miR-30b-3p increased the expression of E-cadherin and $\beta$-catenin by targeting CTHRC1 and ultimately inhibited the EMT process in ovarian cancer cells (Fig. 5).

\section{Discussion}

There is growing evidence that miRNA are widely involved in cancer progression and suppression by regulating thousands of cancer-related genes [10]. MiRNAs have been confirmed that they have the potential for early cancer diagnosis and to predict therapeutic response and prognosis [11]. It is estimated that miRNAs control the activity of over $50 \%$ of all protein-coding genes in mammals [12] and are involved in the regulation of almost all cellular processes [13]. A lot of studies have shown that abnormal miRNA expression is associated with various human diseases including ovarian cancer $[14,15]$. It has been identified that miR-30b upregulated in numerous malignancies including medulloblastoma [16], oral squamous cell cancer [17] and parathyroid carcinoma [18]. These results support the idea that mir-30b is an oncogene for these tumors. Nevertheless, miR-30b may also play a role as a tumor suppressor. Mir-30b expression has been found to be reduced in a variety of human cancers, such as gastric cancer [19], non-small cell lung cancer [20], and colorectal cancer [21, 22], indicating that miR-30b could suppress the invasion and migration of cancer cell and inhibit the proliferation of cancer cell. However, the mir-30 family has been less studied in ovarian cancer. Shi et al. [23] found that the high expression of miR-30 family was associated with the increase of OS/ PFS in ovarian cancer, and the conclusion is that miR30 family can be a reliable prognostic marker of ovarian cancer. The OncoLnc dataset showed that the increased expression level of miR-30b-3p was related to better OS [24]. These finding suggested that miR-30 family can act a tumor suppressor for ovarian cancer.

In this study, we first investigated the effect of mir$30 \mathrm{~b}-3 \mathrm{p}$ on the biological function of ovarian cancer cells. The relative expression levels of miR-30b-3p in ovarian cancer cells line OVCAR3 and normal ovarian cells line IOSE- 80 were detected by qRT-PCR, and the results showed that the expression of miR-30b-3p in OVCAR3 cells was lower than that in IOSE-80 cells. Mir-30b-3p was overexpressed in OVCAR3 cells by transfection. The overexpression of miR-30b-3p could inhibit the proliferation of OVCAR3 cells, slow down the cell division cycle, promote apoptosis, and reduce the migration and invasion of OVCAR3 cells. The results indicated that miR30b-3p was a tumor suppressor gene for ovarian cancer.

Mir-30b-3p mainly affects the cell function of ovarian cancer by regulating its target genes. Bioinformatics analysis showed that mir-30b-3p was complementary to the 3'-UTR of CTHRC1. Therefore, the mutual regulation between the two was further verified by the luciferase reporting experiment, and it was found that miR-30b-3p could significantly inhibit the activity of luciferase, confirming that CTHRC1 was the target gene of miR-30b-3p.

CTHRCI is a secreted glycosylated protein, which was first found in the balloon injury model of rat and promotes cell migration by inhibiting collagen type I deposition [25]. Previous studies have shown that CTHRC1 is highly expressed in a variety of tumors and can be a prognostic factor for non-small cell lung cancer, liver cancer, gastrointestinal stromal tumor, pancreatic cancer, and colorectal cancer [26-29]. The mechanism of CTHRC1 in promoting tumor invasion and metastasis varies among different types of tumors. In colorectal cancer, CTHRC1 can enhance Erk phosphorylation, up-regulate MMP-9 expression, and promote extracellular matrix degradation, thereby promoting tumor cell invasion [30]. In addition, CTHRC1 promotes cell migration and adhesion through regulation of the Src/FAK signaling pathway in pancreatic cancer and integrin $\beta 1$ in hepatocellular carcinoma [31, 32]. Hou et al. [28] showed that increased expression of CTHRC1 in epithelial ovarian cancer can induce EMT in ovarian cancer cells, thereby promoting tumor cell invasion and metastasis. EMT is a process of molecular reprogramming and phenotypic change, which transforms polarized stationary epithelial cells into moving mesenchymal cells, thus resulting in malignant transformation and metastasis [33]. Studies have described that the dysregulated mir-30 family regulates multiple signaling pathways leading to tumor EMT, which plays a key role in tumor invasion and metastasis [9, 34]. On the other hand, some members of miR-30 family may also function as an EMT inhibitor, blocking the proliferation, invasion and metastasis of cancer cells [35]. In the study of Ye et al. [35], it was found that the expression level of mir-30 s in ovarian cancer cell lines was decreased after TGF- $\beta$ induced EMT. On the contrary, overexpression of miR-30d could block EMT induced by TGF- $\beta$. It was confirmed that miR-30d directly bound to Snail's 3 '-UTR to inhibit its expression, thus inhibiting the EMT process.

To determine whether mir-30b-3p inhibits the migration and invasion ability of ovarian cancer cells through 
the regulation of EMT in OVCAR3 cells, this study tested the functional proteins related to EMT. The results showed that the overexpression of mir-30b-3p significantly reduced the expression of CTHRC1 protein, significantly increased the expression of E-cadherin and $\beta$-catenin, and significantly decreased the expression of Snail protein. This result indicated that mir-30b-3p inhibited the EMT process by binding to the 3'-UTR of CTHRC1, thereby inhibiting the migration and invasion ability of ovarian cancer cells. We first report that the direct regulation of CTHRC1 by miR-30b-3p.

\section{Conclusion}

In summary, miR-30b-3p plays an anti-cancer role in ovarian cancer. The high expression of mir-30b-3p can inhibit the biological function of ovarian cancer cells. Mir-30b-3p can regulate the expression of EMT-related proteins and prevent the development of EMT in ovarian cancer cells by targeting and inhibiting the expression of CTHRC1. For the past few years, more and more evidences have shown that miRNAs have great potential in early detection, prognosis and chemotherapeutic sensitivity of ovarian cancer. Our study provides scientific basis for miR-30b-3p as a diagnostic or prognostic indicator for ovarian cancer. However, it is worth noting that the study has no conduct relevant clinical trials and animal model experiments. Hence, it is necessary to conduct further research upon our current research results.

\section{Abbreviations \\ qRT-PCR: Quantitative reverse transcription polymerase chain reaction; CCK-8: Cell-counting kit-8; CTHRC1: Collagen triple helix repeat-containing 1; EMT: Epithelial-mesenchymal transformation; 3'UTR: $3^{\prime}$-Untranslated region; PI: Propidium iodide; PBS: Phosphate buffer solution.}

\section{Acknowledgements}

Not applicable.

\section{Authors' contributions}

$Y L$ and JZ were responsible for the design of the whole study. JW and YZ were in charge of experimental operation and drawing. XC was responsible for writing the manuscript. YC submitted the manuscripts. All authors read and approved the final manuscript.

\section{Funding}

This work was supported by National Natural Science Foundation of China (Nos. 81672560, 81772773, 81302275), Jiangsu Provincial Medical Youth Talent (No. QNRC2016753), and The Project of Jiangsu Provincial Maternal and Child Health Association (No. FYX201709).

\section{Availability of data and materials}

The data and materials of this experiment are available.

Ethics approval and consent to participate

Not applicable.
Consent for publication

Manuscript is approved by all authors for publication.

\section{Competing interests}

No conflict of interest exits in this manuscript.

\section{Author details}

${ }^{1}$ Department of Obstetrics and Gynecology, The First Affiliated Hospital of Soochow University, 188 Shizi Road, Suzhou 215006, Jiangsu, People's Republic of China. ${ }^{2}$ Department of Obstetrics and Gynecology, The First People's Hospital of Yancheng, Yancheng 224001, Jiangsu, People's Republic of China.

Received: 17 December 2019 Accepted: 5 March 2020

Published online: 10 March 2020

\section{References}

1. Alexandrov LB, Nik-Zainal S, Wedge DC, Aparicio SA, Behjati S, Biankin AV, Bignell GR, Bolli N, Borg A, Borresen-Dale AL, Boyault S, Burkhardt B, Butler AP, Caldas C, Davies HR, Desmedt C, Eils R, Eyfjord JE, Foekens JA, Greaves M, Hosoda F, Hutter B, Ilicic T, Imbeaud S, Imielinski M, Jager N, Jones DT, Jones D, Knappskog S, Kool M, Lakhani SR, Lopez-Otin C, Martin S, Munshi NC, Nakamura H, Northcott PA, Pajic M, Papaemmanuil E, Paradiso A, Pearson JV, Puente XS, Raine K, Ramakrishna M, Richardson AL, Richter J, Rosenstiel P, Schlesner M, Schumacher TN, Span PN, Teague JW, Totoki Y, Tutt AN, Valdes-Mas R, van Buuren MM, van't Veer L, Vincent-Salomon A, Waddell N, Yates LR, Australian Pancreatic Cancer Genome Initiative, ICGC Breast Cancer Consortium, ICGC MMML-Seq Consortium, ICGC PedBrain, PedBrain I, Zucman-Rossi J, Futreal PA, McDermott U, Lichter P, Meyerson M, Grimmond SM, Siebert R, Campo E, Shibata T, Pfister SM, Campbell PJ, Stratton MR. Signatures of mutational processes in human cancer. Nature. 2013;500:415-21.

2. Torre LA, Trabert B, DeSantis CE, Miller KD, Samimi G, Runowicz CD, Gaudet MM, Jemal A, Siegel RL. Ovarian cancer statistics, 2018. CA Cancer J Clin. 2018;68:284-96.

3. Bray F, Ferlay J, Soerjomataram I, Siegel RL, Torre LA, Jemal A. Global cancer statistics 2018: GLOBOCAN estimates of incidence and mortality worldwide for 36 cancers in 185 countries. CA Cancer J Clin. 2018;68:394-424

4. Cheng CJ, Bahal R, Babar IA, Pincus Z, Barrera F, Liu C, Svoronos A, Braddock DT, Glazer PM, Engelman DM, Saltzman WM, Slack FJ. MicroRNA silencing for cancer therapy targeted to the tumour microenvironment. Nature. 2015;518:107-10.

5. Bartel DP. MicroRNAs: target recognition and regulatory functions. Cell. 2009;136:215-33.

6. Mitchell PS, Parkin RK, Kroh EM, Fritz BR, Wyman SK, Pogosova-Agadjanyan EL, Peterson A, Noteboom J, O'Briant KC, Allen A, Lin DW, Urban N, Drescher CW, Knudsen BS, Stirewalt DL, Gentleman R, Vessella RL, Nelson PS, Martin DB, Tewari M. Circulating microRNAs as stable blood-based markers for cancer detection. Proc Natl Acad Sci USA. 2008;105:10513-8.

7. Nakamura K, Sawada K, Yoshimura A, Kinose Y, Nakatsuka E, Kimura T. Clinical relevance of circulating cell-free microRNAs in ovarian cancer. Mol Cancer. 2016;15:48.

8. Croset M, Pantano F, Kan CWS, Bonnelye E, Descotes F, Alix-Panabieres C, Lecellier CH, Bachelier R, Allioli N, Hong SS, Bartkowiak K, Pantel K, Clezardin P. miRNA-30 family members inhibit breast cancer invasion, osteomimicry, and bone destruction by directly targeting multiple bone metastasis-associated genes. Cancer Res. 2018;78:5259-73.

9. Yang SJ, Yang SY, Wang DD, Chen X, Shen HY, Zhang XH, Zhong SL, Tang $\mathrm{JH}$, Zhao JH. The miR-30 family: versatile players in breast cancer. Tumour Biol. 2017;39:1010428317692204.

10. Di Leva G, Garofalo M, Croce CM. MicroRNAs in cancer. Annu Rev Pathol. 2014;9:287-314.

11. Schwarzenbach H, Nishida N, Calin GA, Pantel K. Clinical relevance of circulating cell-free microRNAs in cancer. Nat Rev Clin Oncol. 2014;11:145-56. 
12. Krol J, Loedige I, Filipowicz W. The widespread regulation of microRNA biogenesis, function and decay. Nat Rev Genet. 2010;11:597-610.

13. Huang Y, Shen XJ, Zou Q, Wang SP, Tang SM, Zhang GZ. Biological functions of microRNAs: a review. J Physiol Biochem. 2011;67:129-39.

14. Kinose $Y$, Sawada K, Nakamura K, Kimura T. The role of microRNAs in ovarian cancer. Biomed Res Int. 2014;2014:249393.

15. Perera RJ, Ray A. MicroRNAs in the search for understanding human diseases. BioDrugs. 2007;21:97-104.

16. Lu Y, Ryan SL, Elliott DJ, Bignell GR, Futreal PA, Ellison DW, Bailey $S$, Clifford SC. Amplification and overexpression of Hsa-miR-30b, Hsa-miR30d and KHDRBS3 at 8q24.22-q24.23 in medulloblastoma. PLoS ONE. 2009:4:e6159.

17. Shao C, Yu Y, Yu L, Pei Y, Feng Q, Chu F, Fang Z, Zhou Y. Amplification and up-regulation of microRNA-30b in oral squamous cell cancers. Arch Oral Biol. 2012;57:1012-7.

18. Rahbari R, Holloway AK, He M, Khanafshar E, Clark OH, Kebebew E. Identification of differentially expressed microRNA in parathyroid tumors. Ann Surg Oncol. 2011;18:1158-65.

19. Tian SB, Yu JC, Liu YQ, Kang WM, Ma ZQ, Ye X, Yan C. MiR-30b suppresses tumor migration and invasion by targeting EIF5A2 in gastric cancer. World J Gastroenterol. 2015;21:9337-47.

20. Zhong K, Chen K, Han L, Li B. MicroRNA-30b/c inhibits non-small cell lung cancer cell proliferation by targeting Rab18. BMC Cancer. 2014;14:703.

21. Zhao H, Xu Z, Qin H, Gao Z, Gao L. miR-30b regulates migration and invasion of human colorectal cancer via SIX1. Biochem J. 2014;460:117-25.

22. Liao WT, Ye YP, Zhang NJ, Li TT, Wang SY, Cui YM, Qi L, Wu P, Jiao HL, Xie YJ, Zhang C, Wang JX, Ding YQ. MicroRNA-30b functions as a tumour suppressor in human colorectal cancer by targeting KRAS, PIK3CD and BCL2. J Pathol. 2014;232:415-27

23. Shi M, Mu Y, Zhang H, Liu M, Wan J, Qin X, Li C. MicroRNA-200 and microRNA-30 family as prognostic molecular signatures in ovarian cancer: a meta-analysis. Medicine. 2018;97:e11505.

24. Zhang S, Lu Z, Unruh AK, Ivan C, Baggerly KA, Calin GA, Li Z, Bast RC Jr, Le XF. Clinically relevant microRNAs in ovarian cancer. Mol Cancer Res. 2015;13:393-401.

25. Pyagay P, Heroult M, Wang Q, Lehnert W, Belden J, Liaw L, Friesel RE, Lindner $V$. Collagen triple helix repeat containing 1, a novel secreted protein in injured and diseased arteries, inhibits collagen expression and promotes cell migration. Circ Res. 2005;96:261-8.

26. Liu W, Fu XL, Yang JY, Yang MW, Tao LY, Liu DJ, Huo YM, Zhang JF, Hua R, Sun YW. Elevated expression of CTHRC1 predicts unfavorable prognosis in patients with pancreatic ductal adenocarcinoma. Am J Cancer Res. 2016;6:1820-7.

27. Ma MZ, Zhuang C, Yang XM, Zhang ZZ, Ma H, Zhang WM, You H, Qin W, Gu J, Yang S, Cao H, Zhang ZG. CTHRC1 acts as a prognostic factor and promotes invasiveness of gastrointestinal stromal tumors by activating Wnt/PCP-Rho signaling. Neoplasia. 2014;16:265-78, 278.e1-13.

28. Hou M, Cheng Z, Shen H, He S, Li Y, Pan Y, Feng C, Chen X, Zhang Y, Lin M, Wang L, Ke Z. High expression of CTHRC1 promotes EMT of epithelial ovarian cancer (EOC) and is associated with poor prognosis. Oncotarget. 2015;6:35813-29

29. Ke Z, He W, Lai Y, Guo X, Chen S, Li S, Wang Y, Wang L. Overexpression of collagen triple helix repeat containing 1 (CTHRC 1) is associated with tumour aggressiveness and poor prognosis in human non-small cell lung cancer. Oncotarget. 2014;5:9410-24.

30. Zhang R, Cao Y, Bai L, Zhu C, Li R, He H, Liu Y, Wu K, Liu F, Wu J. The collagen triple helix repeat containing 1 facilitates hepatitis $B$ virus-associated hepatocellular carcinoma progression by regulating multiple cellular factors and signal cascades. Mol Carcinog. 2015;54:1554-66.

31. Park EH, Kim S, Jo JY, Kim SJ, Hwang Y, Kim JM, Song SY, Lee DK, Koh SS. Collagen triple helix repeat containing-1 promotes pancreatic cancer progression by regulating migration and adhesion of tumor cells. Carcinogenesis. 2013;34:694-702.

32. Chen YL, Wang TH, Hsu HC, Yuan RH, Jeng YM. Overexpression of CTHRC1 in hepatocellular carcinoma promotes tumor invasion and predicts poor prognosis. PLoS ONE. 2013;8:e70324.

33. Zaravinos A. The regulatory role of microRNAs in EMT and cancer. J Oncol. 2015;2015:865816.

34. Zhong Z, Xia Y, Wang P, Liu B, Chen Y. Low expression of microRNA-30C promotes invasion by inducing epithelial mesenchymal transition in nonsmall cell lung cancer. Mol Med Rep. 2014;10:2575-9.

35. Ye Z, Zhao L, Li J, Chen W, Li X. miR-30d blocked transforming growth factor beta1-induced epithelial-mesenchymal transition by targeting snail in ovarian cancer cells. Int J Gynecol Cancer. 2015;25:1574-81.

\section{Publisher's Note}

Springer Nature remains neutral with regard to jurisdictional claims in published maps and institutional affiliations.
Ready to submit your research? Choose BMC and benefit from:

- fast, convenient online submission

- thorough peer review by experienced researchers in your field

- rapid publication on acceptance

- support for research data, including large and complex data types

- gold Open Access which fosters wider collaboration and increased citations

- maximum visibility for your research: over $100 \mathrm{M}$ website views per year

At $\mathrm{BMC}$, research is always in progress.

Learn more biomedcentral.com/submissions 